\title{
inculcating agency
}

andrew divers ${ }^{1}$

united kingdom

abstract

The thought that children should be given greater opportunity to participate meaningfully in affairs which concern them and to show their capacity for reasonable measured thoughts and choices has been displayed by many others (COHEN, 1980; FARSON, 1974; KENNEDY, 1992). It has also been suggested than in order to ensure that we are fair to all individuals, regardless of their age, that our primary consideration should be the capacity for decision making and agency. However, whether or not children are indeed capable of this kind of decision-making and developed agency is greatly contested (most notably perhaps by Plato and Aristotle), and so too are the reasons for this. In what follows then, I will examine the ways in which children may be encouraged to gain this kind of agency, and what our role in facilitating this may be. Moreover, I will show that while difficult, it is possible to approach 'teaching' young people to become autonomous agents in ways that do not interfere with their agency, either presently or in a future-oriented sense. Establishing this is essential as in order to make authentic choices, and allow for holding individuals responsible for their choices, they must be a result of the deliberation of their own choices, and not some other influence, be that external or internal. Finally, in relation to educative aims as a whole, I will follow Seneca's statement above: that education should go beyond inculcating only learning and practises that are of immediate use to the institutions in which they are learned.

key words: autonomy; agency; education.

resumo

\section{inculcando agência}

O pensamento segundo o qual crianças devem receber maiores oportunidades de participar de maneira significativa em assuntos que lhes concernem e de mostrar sua capacidade para pensamentos e ações racionalmente deliberados tem sido mostrado por muitos outros (COHEN, 1980; FARSON, 1974; KENNEDY, 1992). Também tem sido sugerido que, para assegurar o fato de que somos justos com todos os indivíduos independentemente de suas idades, nossa primeira consideração deve ser a capacidade para a tomada de decisão e a agência. No entanto, o fato de as crianças serem ou não de fato capazes deste tipo de tomada de decisão e de agência desenvolvida é altamente contestado (notadamente, talvez, por Platão e Aristóteles), assim como o são também as razões para isso. Assim, no que segue, eu irei examinar os modos pelos quais as crianças deveriam ser encorajadas a adquirir este tipo de agência, e qual deve ser o nosso papel em facilitar isto. Além disso, eu irei mostrar que, ainda que difícil, é ainda assim possível este acesso através do "ensinar" às pessoas jovens como tornarem-se agentes autônomos de uma maneira que não interfira em sua agência, nem em uma perspectiva presente, nem futura. Estabelecer isto é essencial, dado que, para poder realizar escolhas autênticas, e permitir assim que os indivíduos sejam responsabilizados por estas escolhas, elas devem ser o resultado da deliberação acerca de suas próprias escolhas, e não de qualquer outra influência, seja externa ou interna. Finalmente, em relação a objetivos educacionais em geral, seguirei a sentença acima, de Sêneca: de que a educação deve ir além de inculcar apenas aprendizados e práticas que são de uso imediato das instituições nas quais eles são aprendidos.

palavras-chave: autonomia; agência; educação.

${ }^{1}$ E-mail: ajdivers84@gmail.com 
resumen

\section{inculcando agencia}

El pensamiento según el cual los niños y niñas deben recibir mayores oportunidades, para participar de forma significativa en asuntos que les conciernen y para mostrar su capacidad de pensamientos y acciones racionalmente deliberadas, ha sido mostrado por muchas personas (COHEN, 1980; FARSON, 1974; KENNEDY, 1992). También ha sido sugerido que, para asegurar el hecho de que somos justos con todos los individuos independientes de sus edades, lo primero que debemos considerar es la capacidad del individuo de tomar decisiones y de agenciar. Sin embargo, el hecho de que los niños y niñas sean o no de hecho capaces de este tipo de toma de decisión y agencia es altamente cuestionado (de forma notoria, talvez, por Platón y Aristóteles), así como lo son también las razones para esto. Así, a continuación, yo examinaré los modos por los cuáles los niños y niñas deberían ser encorajados a adquirir este tipo de agencia y cuál debe ser nuestro papel en facilitar esto. Además de eso, yo mostraré que, aunque es difícil, es posible el acceso a través del "enseñar" a las personas jóvenes como convertirse en agentes autónomos de una manera que no interfiera en su agencia, ni en su perspectiva presente, ni futura. Establecer esto es esencial, dado que para poder realizar elecciones auténticas y permitir así que los individuos sean responsabilizados por estas elecciones, ellas deben ser el resultado de la deliberación acerca de sus propias elecciones y no de cualquier otra influencia sea interna o externa. Finalmente, en relación a objetivos educaciones en general, seguiré la sentencia, parafraseando a Séneca: de que la educación debe ir más allá de inculcar aprendizajes y prácticas que son para uso inmediato en las instituciones en las que ellas han sido aprendidas.

palabras clave: autonomía; agencia; educación. 
inculcating agency

"Non scholae, sed vitae discimus
[We learn for life, not for school]"

(Seneca, 1965; xiv).

can we 'teach' agency?

Aristotle's view was that it made no sense to educate the young in certain disciplines,

a young man is not a proper hearer of lectures on political science; for he is inexperienced in the actions that occur in life, but its discussions start from these and are about these; and, further, since he tends to follow his passions, his study will be vain and unprofitable. (ARISTOTLE, 1998, p. 3).

But the young to whom Aristotle is referring here is not necessarily what we may expect. He remarks "it makes no difference whether he is young in years or youthful in his character; the defect does not depend on time, but on his living" (ARISTOTLE, 1998, p. 4).

Suggesting that only those who are in a position to appreciate the material they are being presented with be given the opportunity to study it makes sense after all there is little point in teaching those who haven't the faintest idea about what it is they are being taught. I could, for example, demand that I have access to lectures on mathematics but it would make very little sense for me to do since I would not be able to even begin to comprehend that which I was being told. This is certainly true of advanced mathematics and I think I would be rightly turned away were I to send a request to a lecturer of mathematics requesting to attend lectures or receive tuition. The same, though, cannot be said of the basic maths instruction I received whilst at school. "Not to be able to read or write or count or communicate is a tremendous deprivation ... [and]... the first and most immediate contribution of successful school education is a direct reduction of this basic deprivation" (SEN, 2003). The difference between what may be described as further and fundamental education is that in the former case, it is reasonable for the disseminators of the information we are seeking to request that we demonstrate that we are able to comprehend and thus benefit from the tutelage that they will provide us, where in the latter instance it is unquestionable that we will benefit from a basic standard of education. 
With basic, fundamental, education the point is not that we must demonstrate our prowess in our chosen field in order to be given the opportunity to progress and learn more, but that we should be given the opportunity to learn fundamental skills and furthermore be given the opportunity to develop our thinking. Not only this, but we must be able to develop those skills that are necessary for us to live a "good life" (ARISTOTLE, 1998). We have then a definition as to what the primary objectives of basic education should be: to reduce the basic deprivation that occurs from the absence of skills that are needed for a basic standard of living, and to allow us, if we desire and are capable, to progress beyond this basic standard. In short, we must endeavour to help individuals become autonomous developed agents capable of self determination.

\section{the problem with inculcating agency}

If we are too prescriptive in our measures of teaching the undeveloped agent to think autonomously and freely, then we run the risk of negating that very autonomy before it has even had the chance to emerge. As John Dewey put it: "personality cannot be procured for anyone, however degraded and feeble, by anyone else, however wise and strong" (DEWEY, 1969, p. 244).

As Cuypers and Haji (2006) identify, one of the principal aims of any educative process should be to "ensure that...children develop into autonomous critical thinkers" (CUYPERS; HAJI, 2006, p. 723).

A well-known definition of critical thinking comes from Harvey Siegel, who defines it as

(1) the ability to reason well, i.e. to construct and evaluate the various reasons which have been or can be offered in support or criticism of candidate beliefs, judgments, and actions; and (2) the disposition or inclination to be guided by reasons so evaluated, i.e. actually to believe, judge, and act in accordance with the results of such reasoned evaluations. (SIEGEL, 2003, p. 305).

Furthermore, for a critical thinker, such reasons will appropriately move an individual in their thought and action. This appropriate motivation involves both the realisation of the importance of those reasons and also the ability to recognise the evidential force of such reasons in guiding their thoughts and actions. Centrally, 
critical thinking involves the acknowledgement of the binding power of universals, and the ability to think and act in accordance with such universals (BAILIN; SIEGEL, 2003, p. 183-186)

Because of such a definition of critical thinking, such a state is not an all-ornothing one. It is very possible for an individual to have the ability to critically evaluate reasons for action, but to fail to do so in a systematic way, making them a less effective critical thinker than someone who can systematically and consistently do so. Siegel goes further than this in outlining his account of the critical thinker; not only must the aforementioned pre-requisites of critical thinking be fulfilled, but the critical thinker must also have the disposition to seek reasons in support or criticism of their 'candidate beliefs' and must engage readily (and actually) in the assessment of such reasons. Essentially, Siegel's account of the critical thinker can be summarised by saying that the process of becoming a critical thinker involves becoming a certain type of person and not just by learning how to do something. The result of this is that when aiming to educate critical thinkers (or developed agents) then we must aim not simply for children to be able to think critically, but more fundamentally for them to be critical thinkers.

\section{avoiding indoctrination}

Having outlined critical thinking and developed agency as an identityconstituting ideal, we must now turn to explore how the ability to be a developed agent may be inculcated in an autonomous fashion. Fundamentally, we have to avoid making children autonomous in ways that may compromise that very ideal to avoid the criticism of education as Cicero saw it: "obest plerumque iis qui discere volunt, auctoritas eorum qui docent" (most commonly, the authority of those who teach hinders those that would learn) (CICERO, 2003, p. 1i).

The reason why an end result of autonomy that is not achieved in an autonomous way is undesirable may not at first be apparent, however, by forming a strict outline of what constitutes indoctrination, I will show that we must not only help individuals become autonomous, but must do so in a way that respects their current autonomy as much as is possible. 
A helpful way to begin our definition of indoctrination is to outline what it is not. Autonomy includes choice, authenticity and rationality; and in relation to our current question such autonomy must relate not just to the possession of ideals, but to their acquisition as well. The reason why indoctrination is to be avoided is because it compromises this free acquisition of ideals, even the ideal or ability to be an autonomous thinker. At its core, indoctrination involves the inculcation of beliefs which are non-evidential, and as we saw from Siegel, evidence based reasons for decisions is a central component of critical thinking - so much so that if we attempt to indoctrinate critical thinkers, then it ceases to be critical thinking at all. But the importance of autonomy as an educational ideal and as the natural opposite to indoctrination goes beyond simply ensuring autonomous choosers. As Dearden writes;

the development of autonomy as an educational aim ... is the development of a kind of person whose thought and action in important areas of his life are to be explained by reference to his own choices, decisions, reflections, deliberations - in short, his own activity of mind. (DEARDEN, 1972, p. 70).

The most important part of Dearden's notion of autonomy as an educational aim is that one's basis for thought must be one's own and nobody else's - our choices and thoughts must be authentic as well as guided by rational reasons to be truly autonomous. After all, I may adopt your reasons for an action and they may well be good, well-thought out, rational reasons, but unless I subject them to scrutiny of my own, they cannot be said to be my reasons as well as yours, however good they may be. Indoctrination compromises this authenticity by permanently disabling an individual's ability to think, believe, or act according to their own reasons, even if the individual in question thinks that they are their own reasons. The idea that one can simultaneously think that one is motivated by one's own reasons for action, and yet not be may seem rather counter-intuitive, and is a particular problem since reason is to some extent self justifying - reason is exactly what our thoughts and actions should be based on. However, my objection to non-authentic reasons can be made clearer by distinguishing between true agency, and proto-agency.

Proto-agents may be distinguished from true agents in the sense that they will be non-autonomous about their beliefs in both the way that they acquire and continue to possess them. A proto-agent may well be able to respond to a question or 
problem by giving reasons, but when pressed about the cause of such reasons may fail to provide an answer which involves their autonomous holding of such a belief (a difference of responding with "so-and-so says this" or "because I have been told" rather than "I think this, because..."). A proto-agent may then be characterised as being enslaved by the reasons of others, rather than freely acting in accordance with their own. To be classed as a true agent, we must act on our own reasons, not those of others. One important way in which we can make the received reasons of others truly our own is to subject them to our own scrutiny: "sibi quisque se vindicet" (everyone must challenge himself, so that he may at least know that he knows) (SENECA, 1965, xxxiii).

\section{open futures}

Indoctrination and manipulation are clearly to be avoided, but how much autonomy can realistically be extended to an educative process? Should the aim be to educate children so that they will as adults have as many options open to them as possible - a 'maximally open' future? Or should the child's future be more specifically shaped in directions that we ourselves endorse?

Perhaps the most well-known supporter of the 'maximising' principle is Joel Feinberg. In The Child's Right to an Open Future, he argues that children have “anticipatory autonomy rights" (FEINBERG, 1992, p. 76-97). These rights, says Feinberg, are violated when a child's future options are prematurely closed, and honoured when these future options are kept open. According to Feinberg, we should send a child "out into the adult world with as many open opportunities as possible, thus maximising his chances for self-fulfilment" (FEINBERG, 1992, p. 84).

At first glance, this is an attractive prospect. Even though we want children to grow into adults, we do not want to decree what sort of adults they will be. Indeed, since the aim should be for a child to be an autonomous adult, we should encourage them to be adults who can make their own choices as to what sort of person they will be, and what endeavours they themselves choose to pursue. In stipulating too strongly or too early what they should focus on, we may irreversibly close some doors for them, even if we are only trying to open others. 
There are two main objections to this 'maximising' principle. One is that attempting to approach children's futures in such a way does little more than make many paths inaccessible to the child in any fundamental way by trying to keep them all open. Feinberg's encapsulation of an open-future requires that we must give the child as many opportunities as possible. Let us consider a child whose parents are keen for them to be able to 'try everything'. In pursuing too many activities, each activity is devalued. Moreover, we can never be good at anything if we are constantly under pressure to do everything. Thus, any supposed benefit received from this approach is lost by the necessary shallow-ness of our relationship with each endeavour. Even if we show prowess and enjoyment for any one thing, we are still compelled to go off and try something else. The other objection is that in 'trying everything', our hypothetical child does nothing more than become a machine with a duty to turn their hand to everything so as not to deny themselves any future possibility - having football practise on a Monday, violin lessons on a Tuesday, dance on a Wednesday, and so on, to the point where they are no longer allowed any time to enjoy being a child, to play or relax (something they would themselves likely choose to do). Encouraging maximum choices in the future disregards the child as important right now, instead favouring only that which they may become.

Raz (1986) offers a more temperate formulation of the maximising principle suggesting that while it is important to increase choices this does not entail maximising such choices indefinitely. For Raz it is the range of choice and not the number of choices that are of import: "A choice between hundreds of identical and identically situated houses is no choice, compared with a choice between a town flat and a suburban house, for example" (RAZ, 1986, p. 375). Yet ultimately, this notion is no more helpful than Feinberg's maximising principle. It is not clear how we are to interpret the difference between a range of choices as opposed to a myriad of identical choices. Of course in some cases it will be obvious that there is a significant difference between two choices. Raz's town flat and suburban house or a child's pursuit of sports or music constitutes an easily distinguishable range of choice. But other choices are not so clear - is a north-facing flat too similar to a south-facing one of the same design, or playing rugby too similar to playing football, to constitute an 
adequate range of choice? How are we to interpret the content of these choices so as to adhere to Raz's assertion? If some decisions are too similar to be of use to Raz's system of choice, then does this mean that we are driven to offer choices that are maximally different, just for the sake of offering an adequate range of choice? For example, Raz's town flat and suburban house are different, but not as different as a yurt or a tree-house. Are we then pressed to entertain these as real possibilities as an abode? In the case of children, the choice to pursue music or sports constitutes less of a range of choice than the choice to be destitute, or to join a guerrilla army, but surely we cannot endorse giving children 'a taste' of such a life just so they can see if they like it or not. The fundamental problem with Raz's suggestion that range of choice must be increased is that it is generally unhelpful because it is so difficult to appraise what this may mean in any real applicable way. Moreover, it could easily be interpreted in ways that are clearly unhelpful to a child's future wellbeing.

It is most often assumed that parents have their children's best interests at heart. But are we to conclude that this always makes them the best judges of which directions to guide their children? How can we protect the child from an overbearing parent who tries to push their child to achieve things that the parent and not the child endorse? One answer may be to appeal not just to the child's future autonomy, but to the child's present autonomy. Although it may be argued that (especially young) children lack more than the simple display of preferences, there is no saying that this cannot suffice to allow them to dissent from pursuing certain activities. When talking about basic education though, we must measure the detrimental effect that allowing the child to refuse to participate in educational activities will have. For example, no matter how much a child may hate reading, this does not mean that we should cease to strongly encourage them do so, since illiteracy in later life will undoubtedly have a more profound negative impact than will the lack of enjoyment they experience whilst learning. Moreover, it is likely that our hope is that they will come to appreciate reading the more of it that they do. In terms of other activities however, this obligation is not apparent. Staying with the sporting analogy, we are not bound to force a child to play football even though it could be argued that doing so will allow them to make a handsome living in their adult years. The point is that 
reading is a fundamental skill in the same way that sporting prowess is not. All told, in regards to 'open futures', we should be guided by the principle that we should allow the child to develop future interests not maximally, nor by what we would choose for them - but instead by actually listening to children, and developing skills and keeping the paths open which the children themselves show enthusiasm towards pursuing. The child then should be educated not only to an open future of self-fulfilment, but to a more fulfilling life right now and in the future which they can carry with them into adulthood, on their own terms.

\section{autonomy in learning as well as from it? educative democracy}

We may fail children by giving them a maximally open future (and not just for pragmatic reasons) and so clearly some limit on what is offered is not only inevitable, but necessary. The question of what that limit should be still remains. If the aim is to foster autonomy in the future and also to honour the autonomous individual in the present, then we may be tempted to suggest that the best way to educate children is to allow them to choose what they learn and in what manner; or indeed to allow them to reject some forms of education altogether. Though in some instances we may want to allow the freedom to choose one programme of education over another, this cannot be the case when we are talking about fundamental education. The reason for this is that an individual may reject any education whatsoever. Strongly autonomous education which allows anyone to reject it may give the child less than they need or deserve from their education, but even so we still do not want to be left with our only choice being to indoctrinate children, even if it is for their own good.

We can, however, conceive a weaker educational autonomy that manages to reconcile the notions of honouring present autonomy and inculcating future capacity for autonomy. For an individual to be said to have views autonomously, these views must be both acquired and held autonomously. A child may reasonably be said to be autonomous with respect to the acquisition of a belief - even an instilled one - if its acquisition does not subvert responsibility for any actions which issue from that belief. Furthermore, in respect of autonomously possessing beliefs, an agent is 
autonomous iff throughout the period of the possession of that belief the agent in question is capable of rejecting that belief and thus avoids the continued holding of those beliefs being a product of indoctrination. Lastly, we must be sure in order for an agent to be autonomously influenced by a desire that they have the ability to act (or not to act) freely upon such an influence.

\section{education as ushering the child into that which is considered good}

The reason why allowing an individual to turn their back on education would be a mistake is because of the fundamental aim of education - ushering the child into that which is 'good'. Hitherto we have seen (from Sen) that one fundamental aim of education should be to reduce the disadvantages suffered by individuals who do not receive a basic standard of education, and from Dearden that autonomy should be an aim of any educative system. What both of these views about education have in common is that they are both concerned with initiating children into those things which are considered good. That autonomy is a good thing, and that avoiding the deprivation of a lack of basic education is also good I take to be uncontroversial. Furthermore, by categorising the over-arching aim of education thus it allows us to make more prescriptive statements about what is considered a good focus for education. It also avoids the problems associated with a totally free educative process that were outlined above.

Underpinning all of the above is the thought that all education must be authentic. An authentic education must at heart be forward-looking, not least because of the necessary interference on the part of the educators. What preserves this authenticity is instilling the abilities to autonomously possess and be influenced by those things which we are taught and, on a weaker conception of autonomy, to receive those ideas in an autonomous fashion. Essentially, although driven by the outside forces of education and its educators, the process of learning must be an internal one. As Feinberg (1986) writes:

Always the self that contributes to the making of the newer self is the product both of outside influences and an earlier self that was not quite as fully formed... At every subsequent stage the immature child plays a greater role in the creation of his own life, until...he is at last fully in charge of himself. [...] Perhaps 
we are all self-made in the way just described, except those who have been severely manipulated, indoctrinated, or coerced throughout childhood. (FEINBERG, 1986, p. 34).

But even though we may be 'self-made' in the way described above, Feinberg still asserts that we cannot do this independently, even if we may do so autonomously and authentically. "The self we have created in this way for ourselves will not be an authentic self unless the habit of critical self-revision was implanted in us early" (FEINBERG, 1986, p. 35, Italics added). It is this distinction that is of most importance here - we must not confuse autonomous education with independent education.

\section{is self determination theory the answer?}

How might we go about setting up the kind of environment that would allow us to foster an autonomous approach to education, while at the same time still salvaging the notion that there are at least some things that are undeniably essential for us to know, even if we disagree? One answer may come from Self-Determination Theory (SDT) (DECI; RYAN, 2000).

Self-determination essentially states that there are two fundamental types of motivation when determining why an individual is choosing to engage in this or that educative task: these are either autonomous or controlled, and as Deci and Ryan explain, much of the theory has emerged from work examining the effect of extrinsic reward on intrinsic motivation (HEIDER, 1958; CHARMS, 1968; DECI, 1971). Within the broader notion of autonomous or controlled motivators, a spectrum of 5 types of motivation emerges, ranging from what are considered to be the least, to the most autonomous. These motivators are external (according to Deci \& Ryan, the least autonomous) introjected, identified, integrated and intrinsic (the most autonomous form of motivation).

An external motivation is that which is entirely governed by outside forces, and what we can get (or avoid) by performing a given action. In the case of education, we may complete our homework is order to avoid the punishment meted out by failing to do so, or else may put in extra effort with our work to win a prize. 
SDT also states that students possess three basic psychological needs within their experience of education: autonomy, competence and relatedness (DECI; RYAN, 2000).

That someone engages in an activity because they enjoy it is a firm indicator that they have freely chosen that activity, and that their decision is autonomous. Even in the instance of controlled motivation, there is enough of a choice that students are given that allows us to view their actions as autonomous. Desiring a reward is a simple indicator of one's being able to choose: if one is not sufficiently interested in the reward being offered, then it is reasonable to presume that at least some pupils will decline doing the activity which leads to the proposed reward. Even in the case of a more punitive motivation to read being offered - there is still enough of a choice (provided the punishment is not overly harsh) to suggest that if one dislikes reading enough then they can still opt for punishment rather than actually doing the reading. Granted this is not the kind of all-encompassing freedom of choice that we may want, but still represents a sufficient amount of choice to maintain some kind of autonomy in the learning process, even if it is somewhat curtailed by having to choose the 'lesser of two evils' in some instances.

Such a theory can be readily transposed to our current examination of educative processes that are designed to promote autonomy. As has been mentioned earlier basic educational skills such as basic standards of literacy and numeracy are essential if we are to be able to pursue (or discontinue) certain avenues of education: after all for a choice to be autonomous, it must also be informed. How then might we at the very least reduce the imposition of will on students who do not desire to study such fundamental skills and knowledge?

For the self-determination theorist, this is achieved through appealing to the right kind of motivations within an individual, and using these to inspire learning. As was mentioned above, the spectrum of autonomy in learning ranges from external to intrinsic - but it is here that the fundamental error within SDT is revealed. It is not prima facie true that intrinsic motivations somehow trump a desire to attain extrinsic rewards in the autonomy game, so to speak. If it is the element of deliberative choice that we value in a system of autonomy, then surely inviting a student to measure up 
the pros and cons of working at something they do not enjoy on the basis that they will get something perhaps unrelated to the endeavour by way of remuneration is every bit as autonomous as relying on the fact that they enjoy the task itself, or that they see the inherent value in doing so? Simply stating that valuing something for its intrinsic value is preferable to the imposition of external factors to motivate learning does little to prove that this is more autonomous, one may even argue that if one cannot help but enjoy something, then the decision to undertake that task (even if we believe that doing so is fundamentally valuable to the individual doing so) is considerably less autonomous than deliberating on whether or not we see a certain amount of self-sacrifice as worthwhile to achieve an extrinsic aim. Furthermore, if we are to point at the neural networks responsible for motivation, it seems even less likely that the SD theorist's claims bear any weight - since there is much evidence to suggest that one's responses to both intrinsic and extrinsic reward are processed in the same way (KOMLOSI et al., 2012; NIEWENHUIS et al., 2005; IZUMA, SAITO, SADATO, 2008). Granted, it may well be better if someone does see the value of the task they are performing in and of itself, but it is not clear that offering incentives (provided that we do not coerce or threaten sanctions) undermines autonomy, or is a lower-order motivation as SDT suggests.

\section{moral education}

We have seen above that when talking about fundamental educational aims, it is how we are able to live, and not our proficiency at exams, essays, or our ability to write a thesis, that is the indictor of a good education. Thus, the goals of a good educative system should be aimed at living a good life and the inauguration into that which is considered good. Moral aptitude is clearly part of what is required for such a life and so a moral education is hugely important. Again we must be able to educate individuals in becoming morally autonomous agents in an autonomous way. Being able to educate in morality does of course imply that some level of expertise in moral matters is possible, and although there is much to be said on the subject of whether or not such a thing is possible (SINGER, 1996; MILL, 2005; 
FEINBERG, 1997; PLATO, 1993) I will for the sake of moving onto how morality may be autonomously inculcated assume that such expertise is indeed possible.

Assuming that it is possible to achieve moral knowledge, one must ask how we may facilitate the development of such knowledge in line with the principles of educative autonomy that have been outlined. We must consider too the thought that acting morally, certainly in the case of acting in line with laws, is constituted by predetermined rules of some kind. Reconciling these two notions seems by no means an easy task - but this is not to say an impossible one.

Durkheim defends the above view that "there is an aspect common to all behavior that we...call moral. All such behavior conforms to pre-established rules. To conduct one's self morally is a matter of abiding by a norm, determining what conduct should obtain in a given instance even before one is required to act" (DURKHEIM, 1961, p. 23) Given this outline of moral behaviour it seems hard to suggest any way in which we may be able to inculcate morality in an autonomous fashion - instead being lead into making children learn by rote those things which are and are not prohibited in the setting in which they find themselves.

But, if we employ our earlier notion of authentic education, a reply to Durkheim emerges. In order to facilitate autonomy it appears that we need to forego it in the present to ensure it develops in the future. Far from breaking the rule of honouring the agency of others however, if an educative process is authentic and the agent upon whom we are inculcating knowledge is an undeveloped one, we foster such agency - leading the agent from an undeveloped to a developed state.

The thought that we need to teach before we facilitate autonomous learning is even more pronounced when we are talking about moral education. In any form of education, but particularly moral education, at least some standard knowledge of relevant concepts is essential for us to be able to grapple with moral questions at all.

Any sort of originality of thought is then only possible once one has grasped a sufficient amount of the basics as it were. But simple mastery of the provenance of morality is nowhere near enough if we are to be able to become morally developed agents capable of thinking and acting in morally autonomous ways. Of course, we must analyse such concepts in order for us to "establish rationally, what faith 
postulates a priori" (DURKHEIM, 1961, p.115). Yet even if we are able to learn and analyse the rules of morality, this still doesn't quite seem enough. We cannot simply learn the rules of morality by rote and analyse them. "To know by roat is no perfect knowledge, but to keep what one hath committed to his memories charge, is commendable: what a man directly knoweth, that he will dispose-of, without turning to his booke or looking to his pattern" (MONTAIGNE, 1886, p. 65 - Italics added). There is then, a performative aspect to displaying moral autonomy - we must not just treat morality as an academic subject - it is a subject for Seneca's 'learning for life'. Such a performative element may be Aristotle's virtuous person, acting in morally 'good' ways, or the autonomous orator of which Kant speaks.

Regarding the indoctrinative aspect of moral education, we must of course avoid the temptation to prescribe which moral theory young people choose to adopt, even if we have strong reasons to prefer one conception of the 'right path' over another. What then are we to take as a common aspect to all moral thought, regardless of it's particular doctrine? A compelling suggestion in this regard may be that an important characteristic of action that may be described as moral rests on the potential for self-sacrifice. That is to say that we are prepared to risk, or actually suffer, some kind of personal detriment in order to comply to our own internal system of values. If we are morally motivated by seeing an act as valuable because we enjoy the feeling of doing 'good' (whatever that conception may mean to us) then we are reduced to the realm of Nagel's moral luck (NAGEL, 1979). In terms of being said to hold a moral code autonomously, to be able to acknowledge that a certain course of action may be considerably less than rewarding to us personally, yet still maintain that such an action be taken because it is the right thing to do, shows a level of deliberation and choice that is the very essence of autonomous thought. So too is it the case that if we do not regard a moral principle - especially one that has been suggested to us by others - as important enough to endure such self-detriment, then we are able to autonomously reject that which we have been taught. In such a case, we may seek a new mode of moral thought in which we do see reasons to undergo such self-sacrifice in order to uphold fundamental tenets which guide our action. 
It seems that the only way in which we are able to facilitate the skills needed for individuals to be autonomous moral agents is to teach them the fundamental tenets that they will need in order to both understand the provenance of morality and to inculcate the critical spirit that is so important to furnish them with the ability to autonomously reject those ways of thinking and the rules that are prescribed. Since morality also has a performative element, we must give children the opportunity to practise moral decisions if we are to expect them to achieve the ability to do so effectively in future. Only then can we be said to have given the child an authentic and autonomous moral education. The reason why such an education is so important is because it is the autonomous action of a developed agent that is central to the praise-/blame-worthiness of any act. If such autonomy ceases to exist, or at the very least we ignore our perfect and imperfect obligations (O'NEILL, 1997) to inculcate such autonomy in agents, then it renders prescriptive statements and censure of acts meaningless.

Given the importance that has been continually placed upon being able (both in regards to competence and opportunity) to exercise our autonomy, this paper has dealt with how, ideally, we may try and ensure that as many individuals as possible attain developed agency. We have also seen that although inculcating agency is to some degree necessary, that to do so in a way that does not compromise or undermine autonomy is something that not only makes sense, but is also possible. We have also discussed how this very endeavour itself may be developed in a way that is sensitive to the current autonomy of any individual we are hoping to educate. Most importantly, we have identified the features of indoctrination, and seen why we must be committed to avoiding this at all costs.

\section{references}

ARISTOTLE (1998). The Nicomachean Ethics. New York, Oxford University Press. BAILIN, S.; SIEGEL, H. (2003). Critical Thinking. The Blackwell Guide to the Philosophy of Education. N. Blake, Smeyers, P., Smith, R., \& Standish, P. London, Blackwell. CHARMS, R. de (1968)._Personal causation: the internal affective determinants of behavior. California, California University Academic Press. CICERO, M. T. (2003). De Finibus Bonorum Et Malorum. Cambridge, Mass., Loeb. COHEN, H. (1980). Equal Rights for Children. NJ, Littlefield, Adams \& Co. 
CUYPERS, S. E.; HAJI, I. (2006). "Education for Critical Thinking: Can it be Nonindoctrinative?". Educational Philosophy and Theory. 38(6): 723-743.

DEARDEN, R. F.; HIRST, P. H.; PETERS, R. S. (1972). Education and the Development of Reason. Bungay, Routledge.

DECI, E. (1971). Effects of externally mediated rewards on intrinsic motivation. Journal of Personality and Social Psychology, Vol 18(1), 105-115.

DECI, E. L.; RYAN, R. M. (1987). The support of autonomy and the control of behavior. Journal of Personality and Social Psychology, 53, 1024-1037.

DEWEY, J. (1969). The School and Society. Chicago, University of Chicago Press.

DURKHEIM, E. (1961). Moral Education. New York, Free Press of Glencoe.

DWORKIN, R. (1985). A Matter of Principal, Harvard University Press.

FARSON, R. (1974). Birthrights. London, Collier Macmillan.

FEINBERG, J. (1992). Freedom and Fullfillment. Princeton, Princeton University Press.

HEIDER, F. (1958). The Psychology of Interpersonal Relations. New York: Wiley.

HOBBES, T. (1985). Leviathan. London, Penguin.

IZUMA, K., SAITO, D. N.; SADATO, N. (2008). Processing of Social and Monetary Rewards in the Human Striatum . Neuron. 58: 284-294.

KOMLOSi et al. (2012). Fluoxetine (Prozac) and Serotonin Act on Excitatory Synaptic Transmission to Suppress Single Layer 2/3 Pyramidal Neuron-Triggered Cell Assemblies in the Human Prefrontal Cortex. The Journal of Neuroscience._32(46): 16369-16378.

MARX, K. (1977). Selected Writings. Oxford, Oxford University Press.

MILL, J. S. (1917). Utilitarianism, Liberty, and Representative Government. Letchworth, Temple Press.

MILLER, D. (1983). "Contraints of Freedom." Ethics 94(1): 66-86.

MONTAIGNE, M. (1886). The Essayes of Michael, Lord of Montaigne. London, Routledge \& Sons.

NAGEL, T. (1979). Mortal Questions. New York: Cambridge University Press

NIEUWENHUIS, S. (2005). Activity in human reward-sensitive brain areas is strongly context dependent. Neuroimage 25: 1302-1309

NOZICK, R. (1974). Anarchy, State and Utopia, Basic Books.

O'NEILL, O. (1988). "Children's Rights and Children's Lives." Ethics 98: 445-463.

PETERS, R. S. (1970). Ethics and Education. London, Allen \& Unwin.

PLATO (1993). The Republic. Oxford, Oxford University Press.

RAWLS, J. (1971). A Theory of Justice, Harvard University Press.

RAZ, J. (1986). The Morality of Freedom. Oxford, Oxford University Press.

SEN, A. (2003). The Importance of Basic Education. Retrieved 25/03, 2017, from

http://www.theguardian.com/education/2003/oct/28/schools.uk4.

SENECA, L. A. (1965). Ad Lucilium Epistulae Morales. Oxford, Oxford Classical Texts. SIEGEL, H. (2003). Relativism Refuted: A Critique of Contemporary Relativism. Dordrecht, Kluwer.

received in: 10.02.2016

accepted in: 02.04.2017 